\title{
PERFORMANCE CHARACTERISTICS OF FLYBACK CONVERTER FED DC MOTOR
}

\author{
Mostafa El-Sayed El-Shebiny
}

Electrical Engineering Department, Faculty of Engineering, Menufiya University, Shebin El-Kom, EGYPT.

\begin{abstract}
:
This paper presents the theoretical and experimental investigation for both dynamic and steady-state operation of a separately excited dc motor fed from flyback dc to dc converter. The effect of duty ratio for different motor excitation levels on the motor performance characteristics are investigated.

The proposed simulation program is performed to predict and describe the system behaviour in starting and steady-state conditions. The computed results for both starting and steadystate are given and proved to be in good agreement with the experimental results.
\end{abstract}

\section{NOMENCLATURE:}

B : Viscous friction coefficient.

C : Capacitance of filter.

E : Battery e.m.f.

$F_{s}$ : Switching frequency.

$i_{m} \quad$ : Instantaneous armature current.

$i_{1} \quad$ : Instantaneous inductor current.

$i_{\text {f }}$ : Motor field current.

J : Moment of inertia.

$k_{m} \quad$ : Back e.m.f. coefficient.

$L_{m}, R_{m}$ : Parameter inductance and resistance.

$L_{1}, R_{1}$ : Input inductance and resistance of the coupling transformer

$T_{L} \quad$ : Load torque.

$T$ : Total period time.

$V_{m} \quad$ : Motor input voltage.

$V_{f} \quad$ : Motor field voltage.

$\omega_{\mathrm{m}} \quad$ : Motor angular speed.

Manuscript received from Dr. Mostafa EI - Sayed EI - Shebiny

Accepted on : $29 / 9 / 2001$

Engineering Research Journal Vol 25,No 1, 2002 Minufiya University, Faculty of Engineering, Shebien El-Kom, Egypt, ISSN 1110-1180 


\section{INTRODUCTION:}

The flyback converter is used as a buck-boost converter using one MOSFET. It is attractive for multiple output application with a better output voltage tracking than most other switching topologies. The saving in cost and size, due to absence of output inductor, is a significant advantage over other switching converter topologies. DC/DC switching regulators may be direct coupled, or they may be isolated by means of a transformer that is sized in accordance with the power level and switching frequency [1-2]. The buck-boost converters are highly discontinuous input and output current which leads to large external filtering requirements [3].

The disadvantage of cuk converter is the requirement of a coupling capacitance with a large ripple current carrying capability [4]. To avoid the above problems, a DC/DC switching regulator is presented in Ref.[1]. In references [5], the system is operated in the discontinuous conduction mode. The continuous conduction mode is preferred but the input current shaping requires more complex control [6-10].

In this paper a flyback converter feeding a separately excited dc motor is presented. Modeling and numerical simulation for this system are given to obtain dynamic and steady-state performance characteristics. The effect of duty ratio for different motor excitation levels on motor performance characteristics is given. The computed results are in a good agreement with the experimental results.

\section{DESCRIPTION OF THE SYSTEM:}

Figure (1) shows the schematic diagram of the system. It consists of a DC/DC flyback converter using one MOSFET and a separately excited dc motor. The dc - dc converter with variable duty ratio which regulates the motor power is a step-up or stepdown converter. The MOSFET is derived by an impulse generator of linear saw tooth carrier voltage. The simulation and experimental results for the gate pulses are shown in Figure (2). The duty ratio for the gate pulses is given as follows:

$$
K=T_{\text {on }} / T
$$


Where, $T_{0 n}$ is the ON period of the MOSFET and, $T$ is the total period.

The time $\left(T_{0 n}\right)$ can be varied by changing the control voltage signal from 0 to 12 volt which is compared with the carrier signal to obtain the gate pulses.

The parameters of the system are given in the Appendix. The MOSFET is turned $O N$ and $O F F$ at a switching frequency $F_{s^{*}}$. The capacitor $C$ is large enough so that the ripple voltages are negligible. When the MOSFET is turned ON, energy stored in $L_{1}$ is increased. Diode $D_{1}$ is inverse-biased and capacitor $C$ discharges to sustain the voltage across the armature of the motor. When the MOSFET is turned OFF, $L_{1}$ discharges energy to charge the capacitor $C$ and supply energy to the motor.

\section{MODELLING OF THE SYSTEM:}

\subsection{Motor Modeling:}

There are two modes of operation for the system as shown in Figure (3). The performance equations for each mode are expressed as follows:

\section{Mode (1):}

In this mode, the MOSFET is turned ON. The differential equations describing this mode can be written as in the following:

$$
\begin{aligned}
& \mathrm{di}_{1} / \mathrm{dt}=1 / \mathrm{L}_{1}\left[-\mathrm{V}_{\mathrm{m}}-\mathrm{i}_{1} \mathrm{R}_{1}\right] \\
& \mathrm{dV}_{\mathrm{m}} / \mathrm{dt}=1 / \mathrm{C}\left[\mathrm{i}_{1}-\mathrm{I}_{\mathrm{m}}\right] \\
& d i_{m} / d t=1 / L_{m}\left[V_{m}-i_{m} R_{m}-K_{m} \omega_{m}\right] \\
& \mathbf{d} \omega_{\mathrm{m}} / \mathbf{d t}=\mathbf{1} / \mathbf{J}\left[\mathrm{K}_{\mathrm{m}} \mathrm{I}_{\mathrm{m}}-\mathrm{B} \omega_{\mathrm{m}}-\mathrm{T}_{\mathrm{L}}\right] \\
& \mathrm{T}_{\mathrm{c}} \quad=\mathrm{k}_{\mathrm{m}} \mathrm{i}_{\mathrm{m}} \\
& \mathrm{i}_{\mathrm{D}} \quad=\mathbf{0}
\end{aligned}
$$

Mode (2):

In this mode, the MOSFET is turned OFF. The differential equations describing this mode can be written as in the following:

$$
\begin{array}{ll}
d i_{1} / d t & =1 / L_{l}\left[E-i_{1} r_{l}\right] \\
d V_{m} / d t & =-i_{m} / C \\
d i_{m} / d t & =1 / L_{m}\left[V_{m}-I_{m} R_{m}-K_{m} \omega_{m}\right] \\
d \omega_{m} / d t \quad=1 / J\left[K_{m} i_{m}-B \omega_{m}-T_{L}\right] \\
T_{e}=k_{m} i_{m} \\
i_{D}=i_{1}
\end{array}
$$




\subsection{Modeling of The Drive Circuit:}

The equation which represents the timing voltage was given by the following expression [8]:

$$
\omega_{\mathrm{a}}=\mathrm{A}[1.0-(\mathrm{X} / \mathrm{T})]
$$

where, $\omega_{\mathrm{a}}$ is the carrier voltage, $\mathrm{A}$ is the maximum voltage (12 Volt), $X$ is any instant which changes from zero to $\pi$ in radians, and $T$ is the chopping period in radians which can be given by:

$$
T=\left(1 / f_{s}\right)
$$

Gate pulse has a value of 12 volt or zero. It has a value of 12 volt when the control voltage is greater than the timing voltage, and it has a zero volt when the control voltage is less than the timing voltage.

\section{EXPERIMENTAL RESULTS:}

The experimental system is built in the laboratory for comparison with the computed results.

\subsection{STEADY-STATE CHARACTERISTICS:}

Figure (4) shows the effect of varying converter duty ratio by varying the control voltage at half and full load motor torque for motor voltage $\left(V_{m}\right)$, motor current $\left(I_{m}\right)$, motor speed $\left(\omega_{m}\right)$ primary voltage $\left(V_{1}\right)$, primary current $\left(I_{1}\right)$ and secondary current $\left(I_{p}\right)$. These results are obtained with field excitation voltage equals to 50 volt.

Figure (5) shows the same results as in Figure (4) but with the field excitation voltage equals to 30 Volt.

Figure $(6,7)$ show the effect of motor current versus motor voltage and motor speed with field excitation voltage of 50 volt and 30 volt at a constant control voltage. The transformation ratio of transformer, for figure (6) is one and for figure (7) is one and half.

It is observed that the motor current and speed are increased with increasing the transformation ratio, this is due to increasing the secondary voltage. It is noticed that the motor speed is increased with decreasing the excitation voltage. 


\subsection{STEADY STATE WAVEFORMS:}

Figure (8) shows the steady-state waveforms of primary voltage $\left(V_{i}\right)$, primary current $\left(i_{1}\right)$, secondary voltage $\left(V_{2}\right)$ and diode current $\left(i_{D}\right)$.

\subsection{STARTING BEHAVIOUR:}

Figure (9) shows the starting behaviour for duty ratio equals to 0.5 at half full load torque for motor voltage $\left(V_{m}\right)$, motor current $\left(i_{m}\right)$ and motor speed $\left(\omega_{m}\right)$. The results shows the validity of the dynamic model as well as soft motor starting.

\section{CONCLUSIONS:}

The steady-state and dynamic behaviour of dc-dc fly-back converter feeding a separately excited dc motor has been investigated. The modeling and numerical simulation have been compared with the experimental results. There are a good agreement between simulation and experimental results. The effect of varying converter duty ratio at half and full load with different field excitation voltage are given. The motor speed is increased with decreasing the excitation voltage. Also, the motor has smooth starting for this system. The results obtained show that the motor, voltage, current and speed are increased with increase in the control voltage. This is due to the increase of secondary voltage. The results shows that the motor voltage and speed are increased with increasing the transformer turns ratio.

\section{APPENDIX:}

The Motor Parameters:

The test motor is a separately excited de motor, 50 volt, 50 watt, 1 Ampere, 3000 r.p.m. It has the following measured parameters:

$$
\begin{aligned}
& R_{m}=10.5 \Omega \quad, \quad L_{m}=0.06 \mathrm{H} \quad, \quad R_{f}=550 \Omega \text {, } \\
& B=0.0001 \mathrm{Nm} /(\mathrm{rad} . / \mathrm{Sec} .) \\
& K_{\mathrm{m}}=0.127 \mathrm{volt} /(\mathrm{rad} . / \mathrm{sec} .) \text {, } \\
& \mathrm{J}=0.0015 \mathrm{~kg} \cdot \mathrm{m}^{2} \text {. }
\end{aligned}
$$

\section{The Fly Back Converter Parameters:}

The parameters of the designed system are:
$\mathrm{L}_{1}=\mathrm{L}_{2}=0.478 \mathrm{H}$
$\mathbf{R}_{1}=\mathbf{R}_{2}=2 \Omega$
$\mathrm{C}=1200 \mu \mathrm{F}$
$f_{\mathrm{s}}=1200 \mathrm{~Hz}$. 


\section{REFERENCES:}

[1] M.A. Ghazy, "A Novel DC/DC Switching Regulator", Al-AZHAR Engineering Third International Conference, Dec. 18-21, 1993. Cairo, EGYPT, pp. 117-128.

[2] Ned Mohan, T.M. Undeland, and W.P. Robbins, "Power Electronics; Converters, Applications and Design", Canada, John Willey \& Sons Inc., 1989.

[3] P.W. Clarke, "A New Switched-Mode Power Conversion Topology Provides Inherently Stable Response", Proceeding of Power No. 10, 1983, pp. E-2-1, E-2-7.

[4] R.P. Massey and E.C. Synder, "High Voltage Single-Ended DC/DC Converter", IEEE Power Electronics Specialists Conference Record, June 1977, p. 156-159.

[5] R. Erickson, M. Madigan, S. Singer, "Design of a Simple highpower-factor rectifier based on the flyback converter", Poroc. IEEE APEC 1990, pp. 792-801.

[6] W. Tang, N. Jiang, G.C. Hua, F-C. Lee, "Power factor correction with flyback converter employing charge control", Proc: IEEE A PEC 1993, pp. 293-298.

[7] J.S. Glaser and A.F. Witulski, "Output plan Analysis of LoadSharing in Multiple-Module Converter Systems", IEEE Transaction on Power Electronics, Vol.9, No.1, January 1994, pp. 43-50.

[8] S.S. Shokralla, S.A. Mahmoud and N.T. Tweig, "A Photo-voltaic System Powered D.C. Motor Controlled By Cuk Converter", Al-Azhar Engineering Sixth International Conference, Septemper 1-4-2000, pp. 55-68.

[9] E. Dallago, A.Danioni and Marco Passoni, "Novel Evaluation of Transient Performance In A DC-DC Flyback Converter", 9th European Conference on Power Electronics and Applications 27-29 August 2001, Graz, Austria.

[10] R. Nalepa, N. Barry and P. Meaney, "A New Control Strategy for Flyback Converters", $9^{\text {th }}$ European Confeence on Power Electronics and Applictions 27-29 August, 2001, Graz, Austria. 


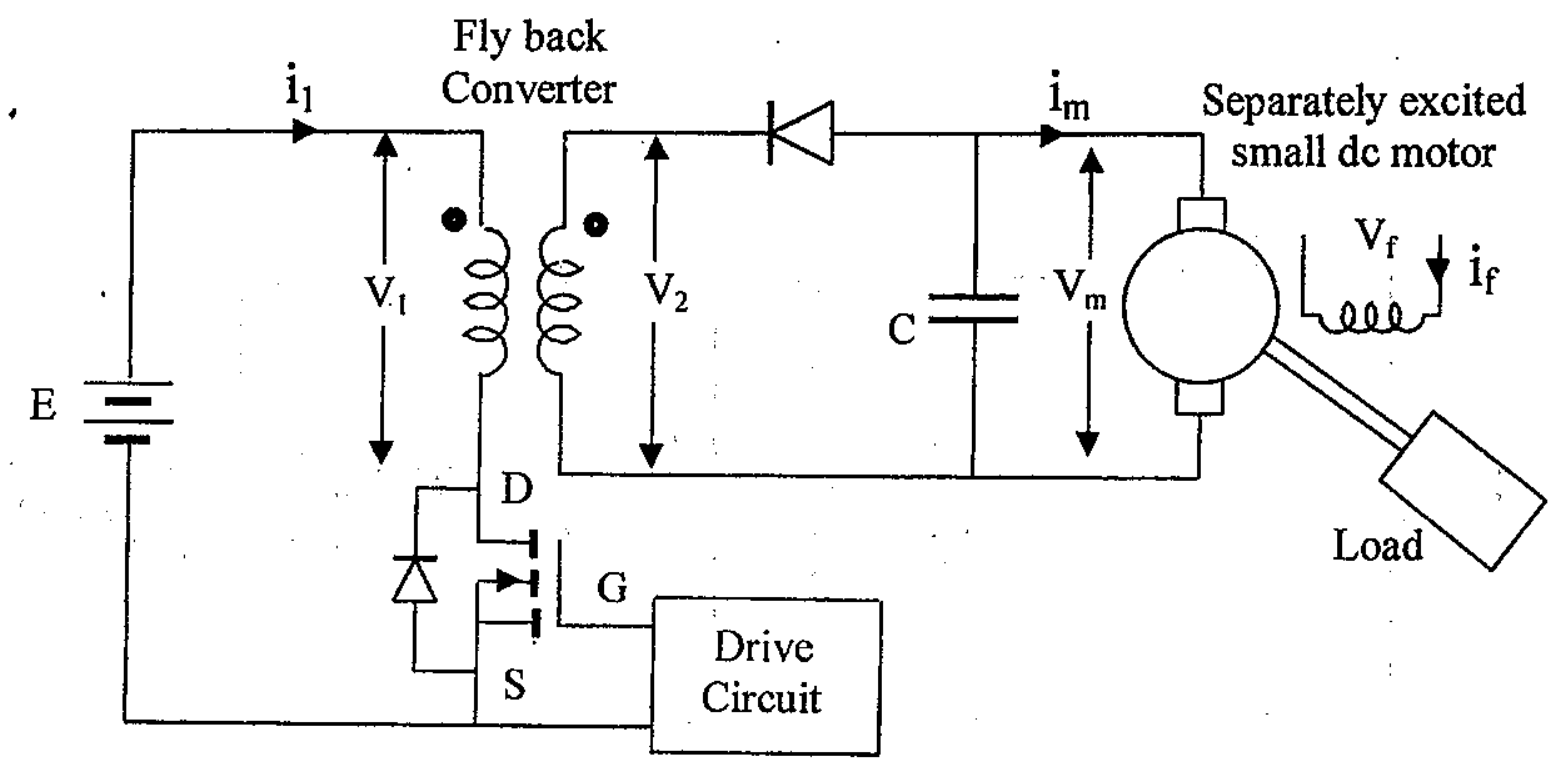

Figure(1) Schematic diagram of the system

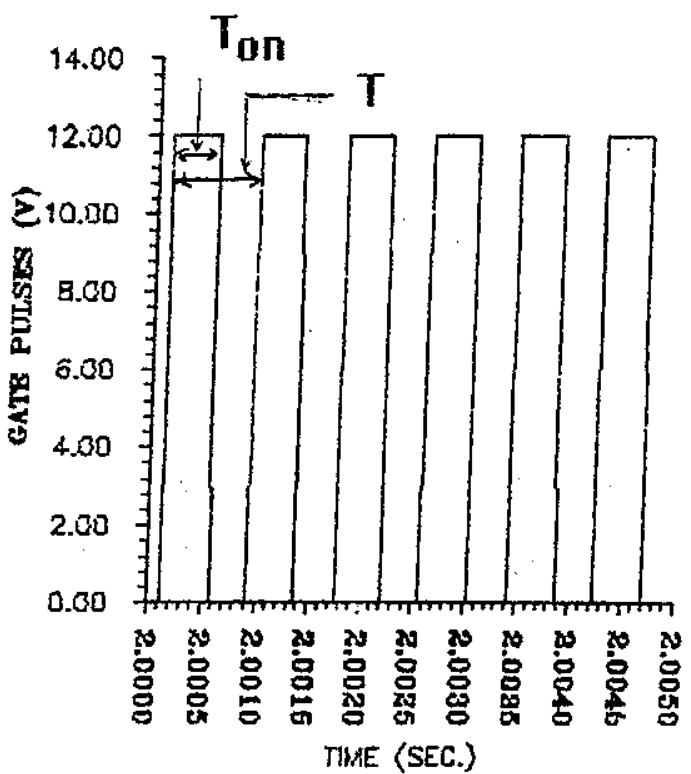

(a) Simulation

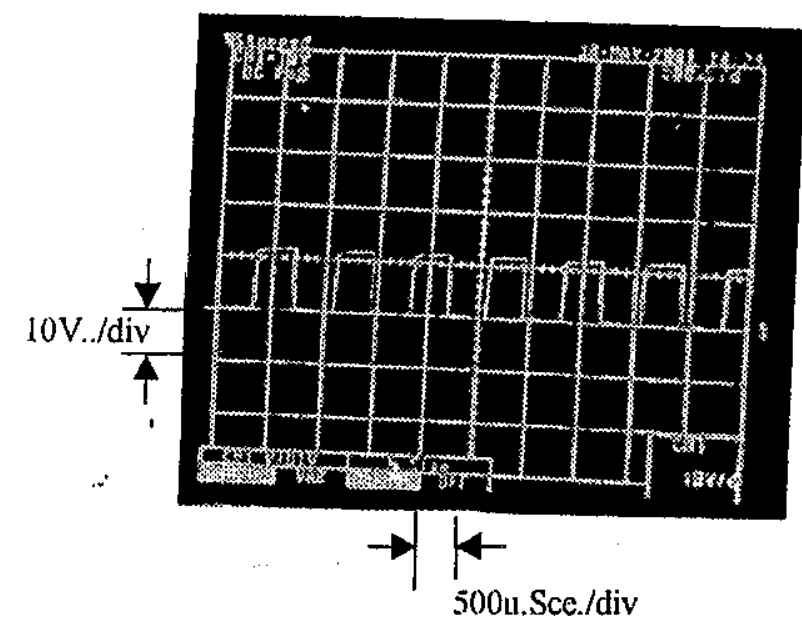

(b) Experimental

Figure(2) Drive circuit gate pulses 


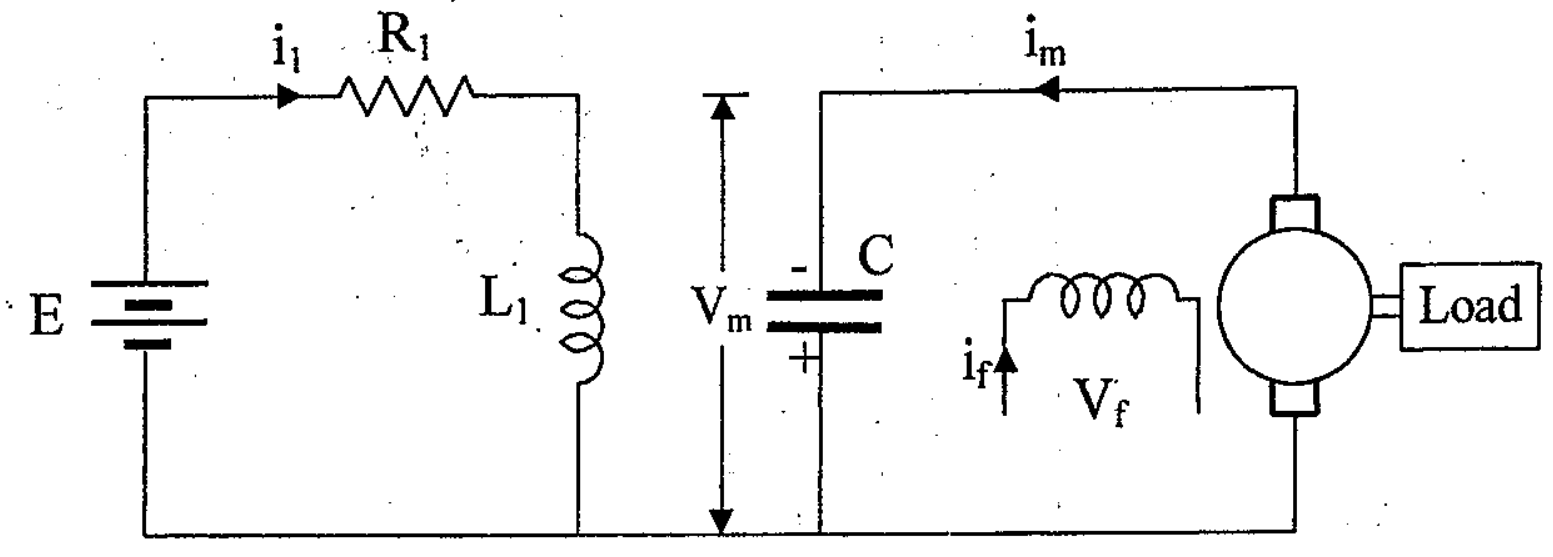

Model (1)

MOSFET is turned ON

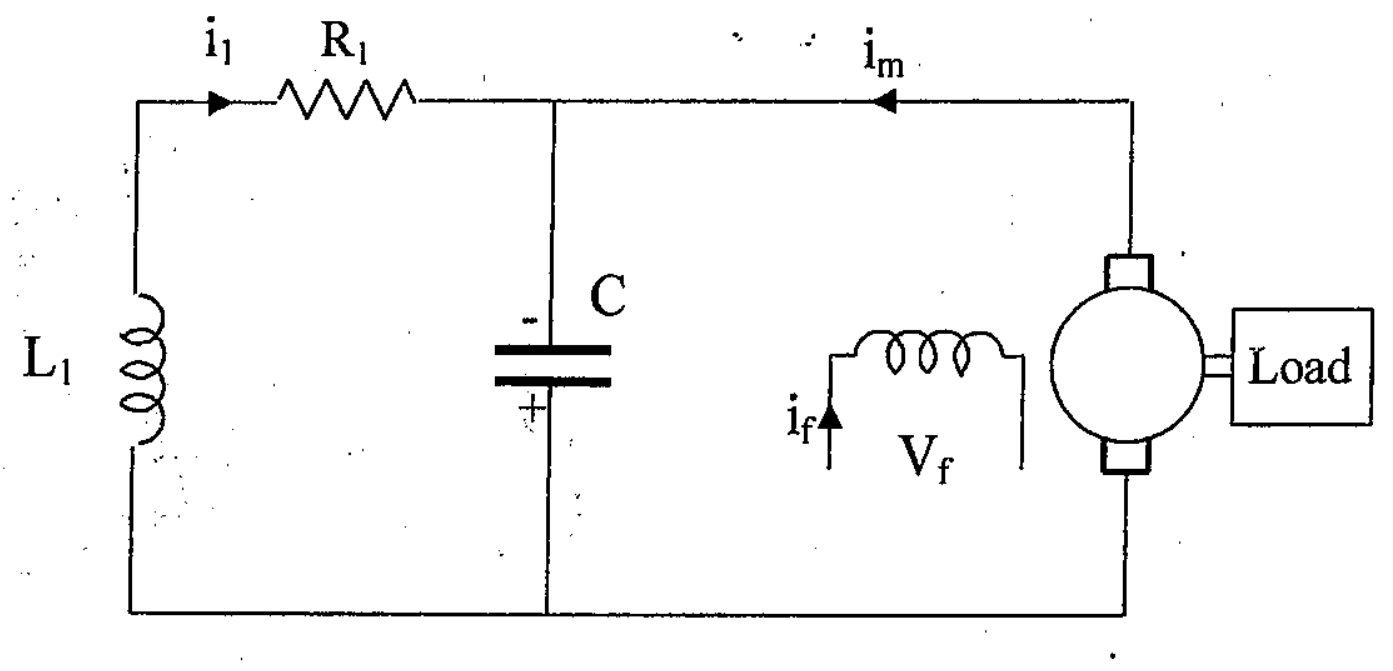

Model (2)

MOSFET is turned OFF

Figure (3) Modes of operation of the system. 

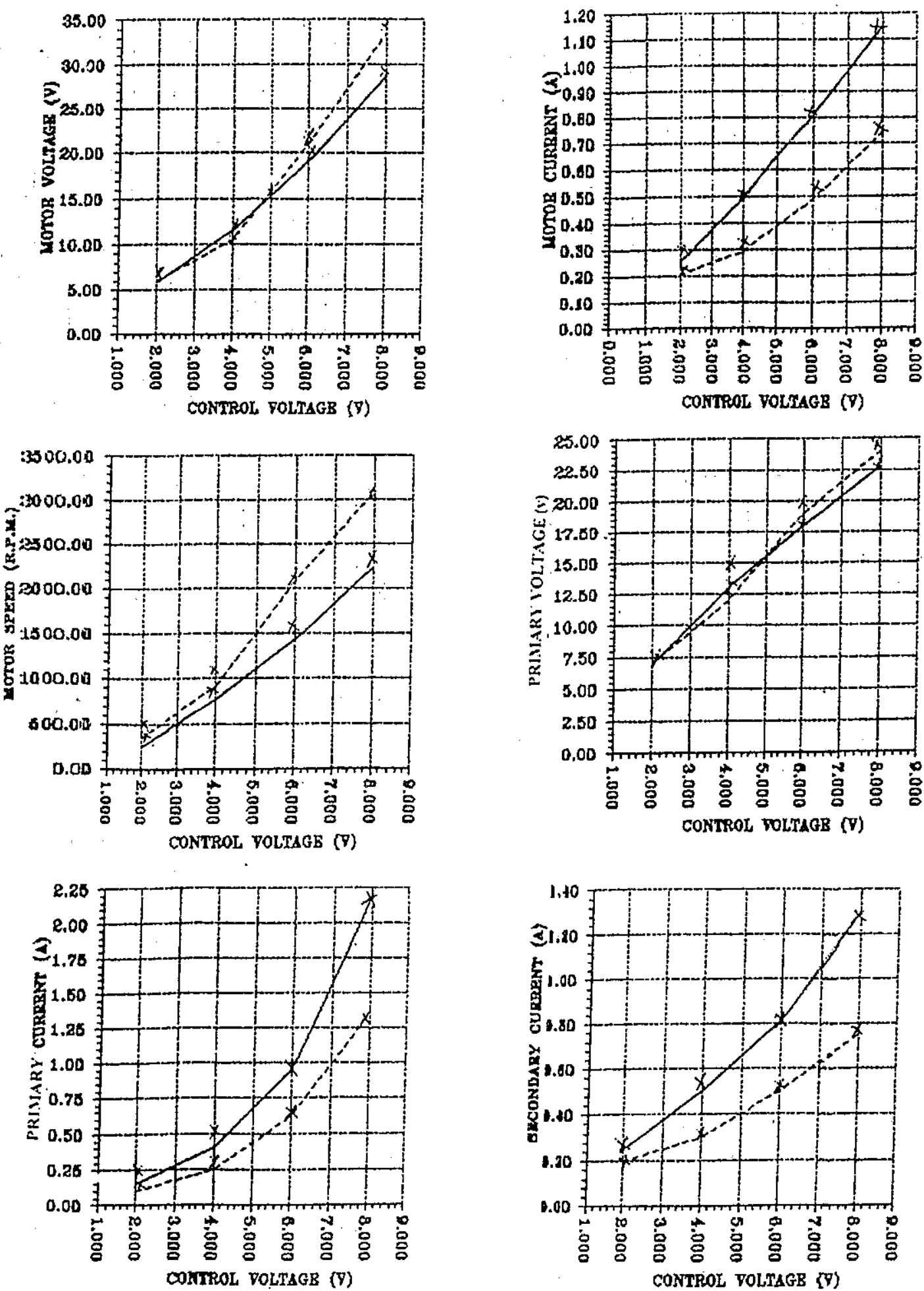

Figure (4): Effect of varying converter control voltage at half and full load torque with field excitation voltage equal to $50 \mathrm{~V}$. full load (computed)

- - - - Half load (computed)

$x \times \times \times \times$ Measured 
OI

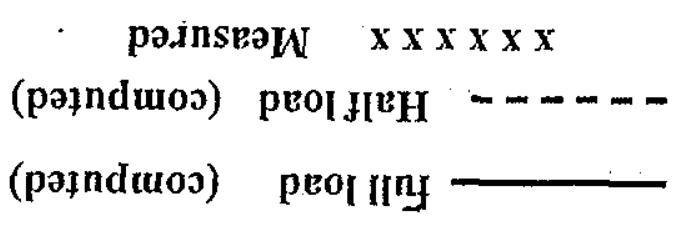

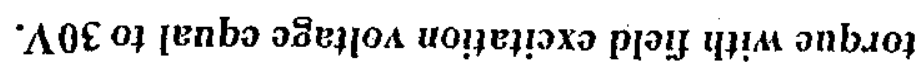

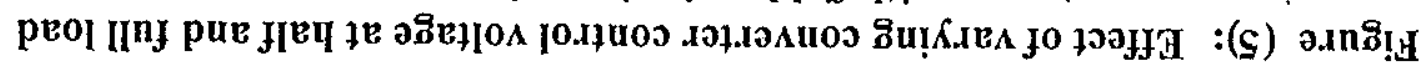

(A) govitas todunos

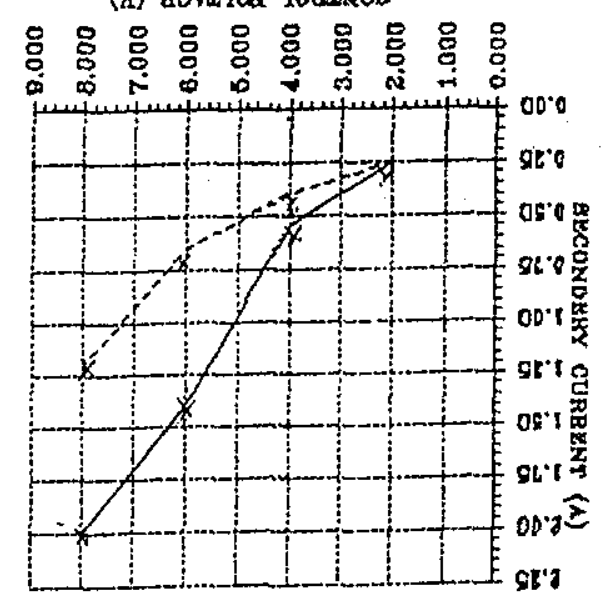

(b) gordTos ToduNas

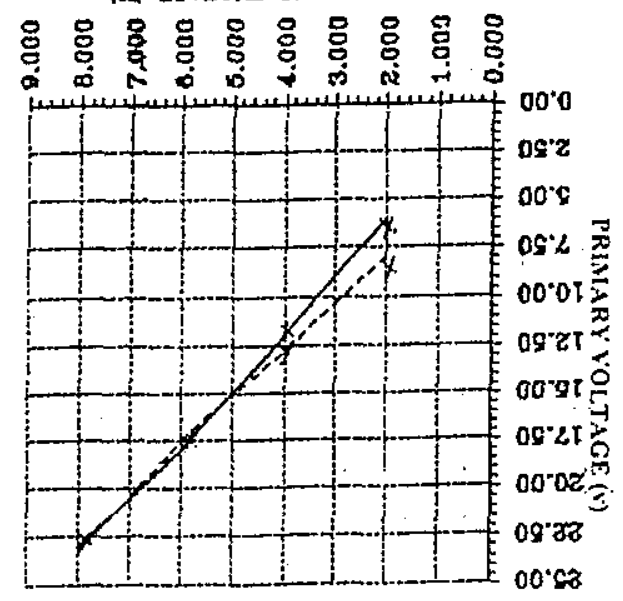

(4) gothtas Todukos

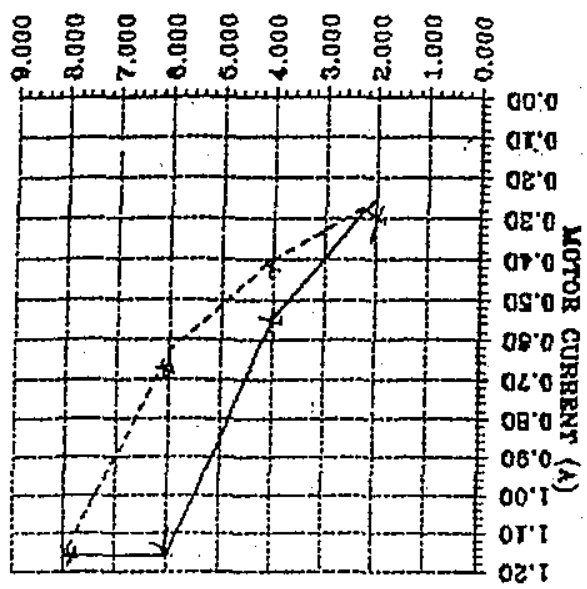

(a) gordTOA TOAXKoo

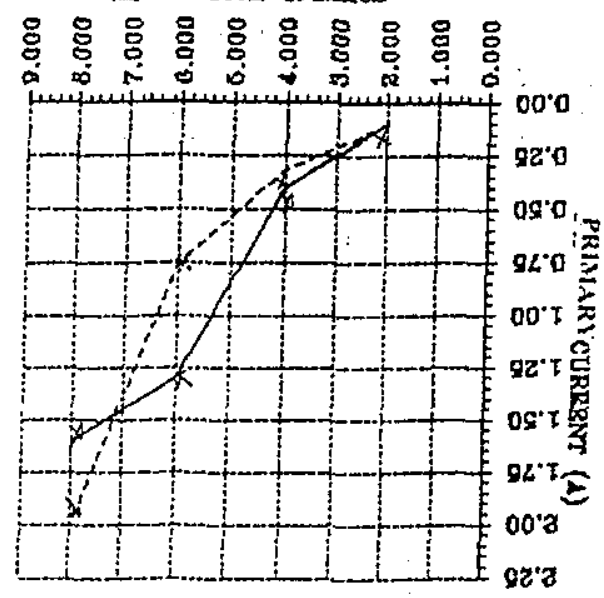

(ه) gavitios Toumico

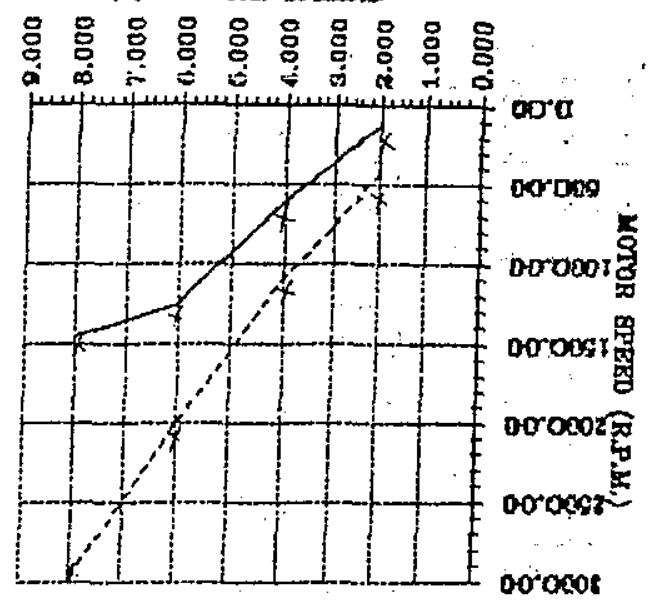

(4) gordTOA TOLINOA

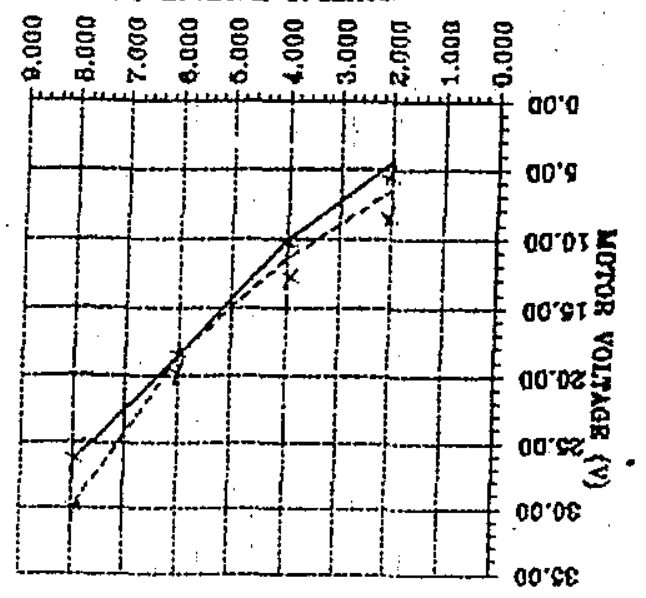



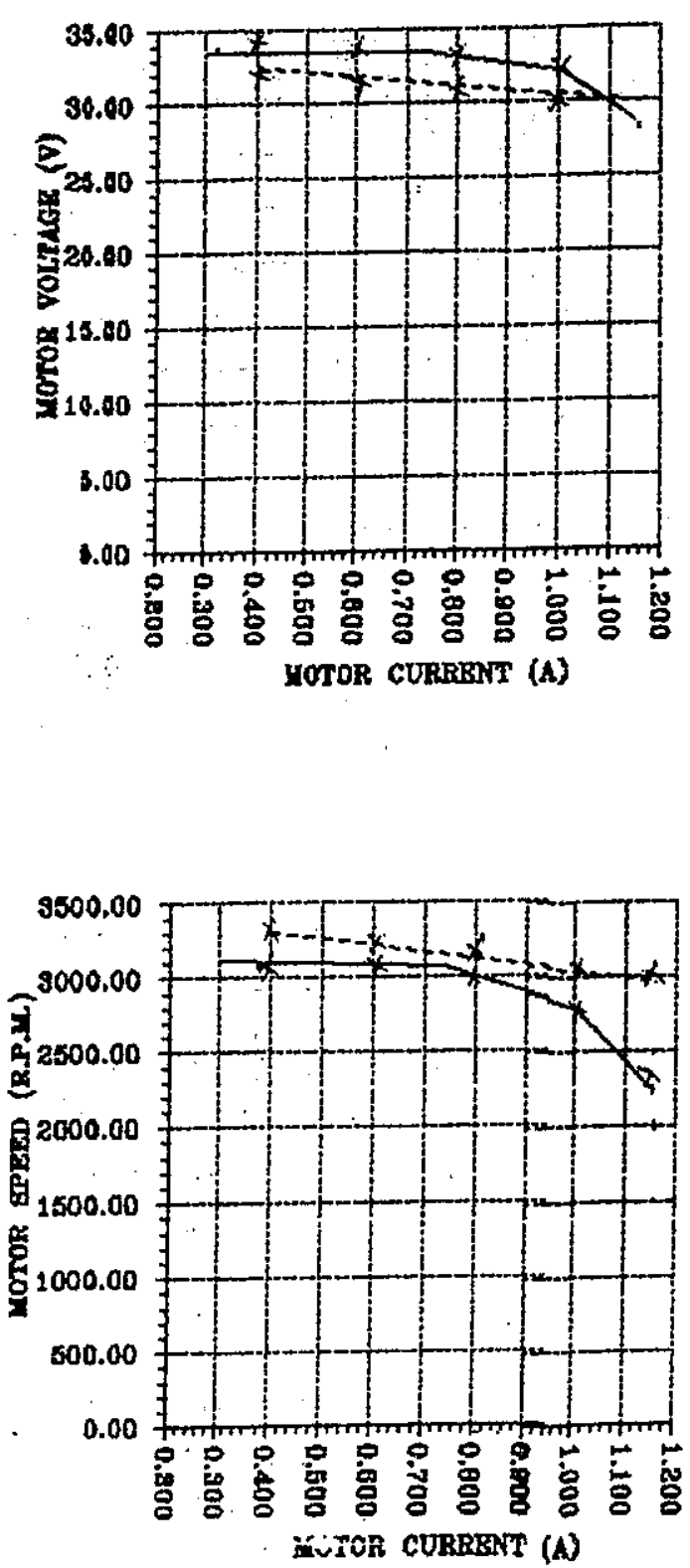

Figure (6): Effect of motor current at constant control voltage (8 volt) with field excitation voltage 30 and 50 volt, $\left(N_{1} / N_{2}=1\right)$

Excitration volt $=\mathbf{5 0} \quad$ (computed)

- - Excitation volt $=30 \quad$ (computed)

$\mathbf{x} \times \mathbf{x} \times \mathbf{x} \quad$ Measured 

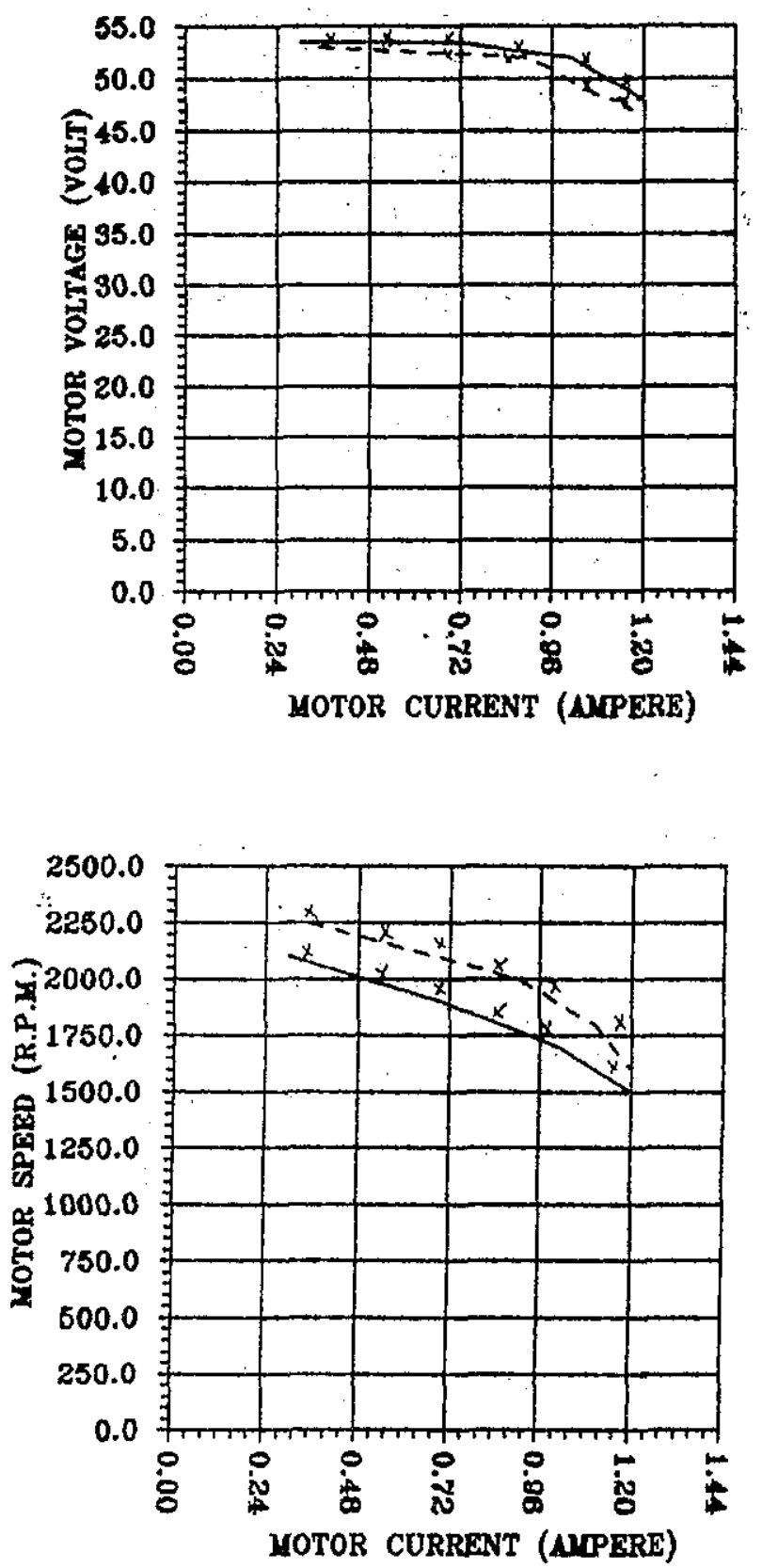

Fig.(7): Effect of motor current at constant control voltage ( 8 volt) with field excitation voltage 30 and 50 volt, $\left(\mathrm{N}_{1} / \mathrm{N}_{2}=1.5\right)$. Excitation voltage $=\mathbf{5 0}$ volt (computed) Excitation voltage $=\mathbf{3 0}$ volt (computed) xxxxxxx Measured. 

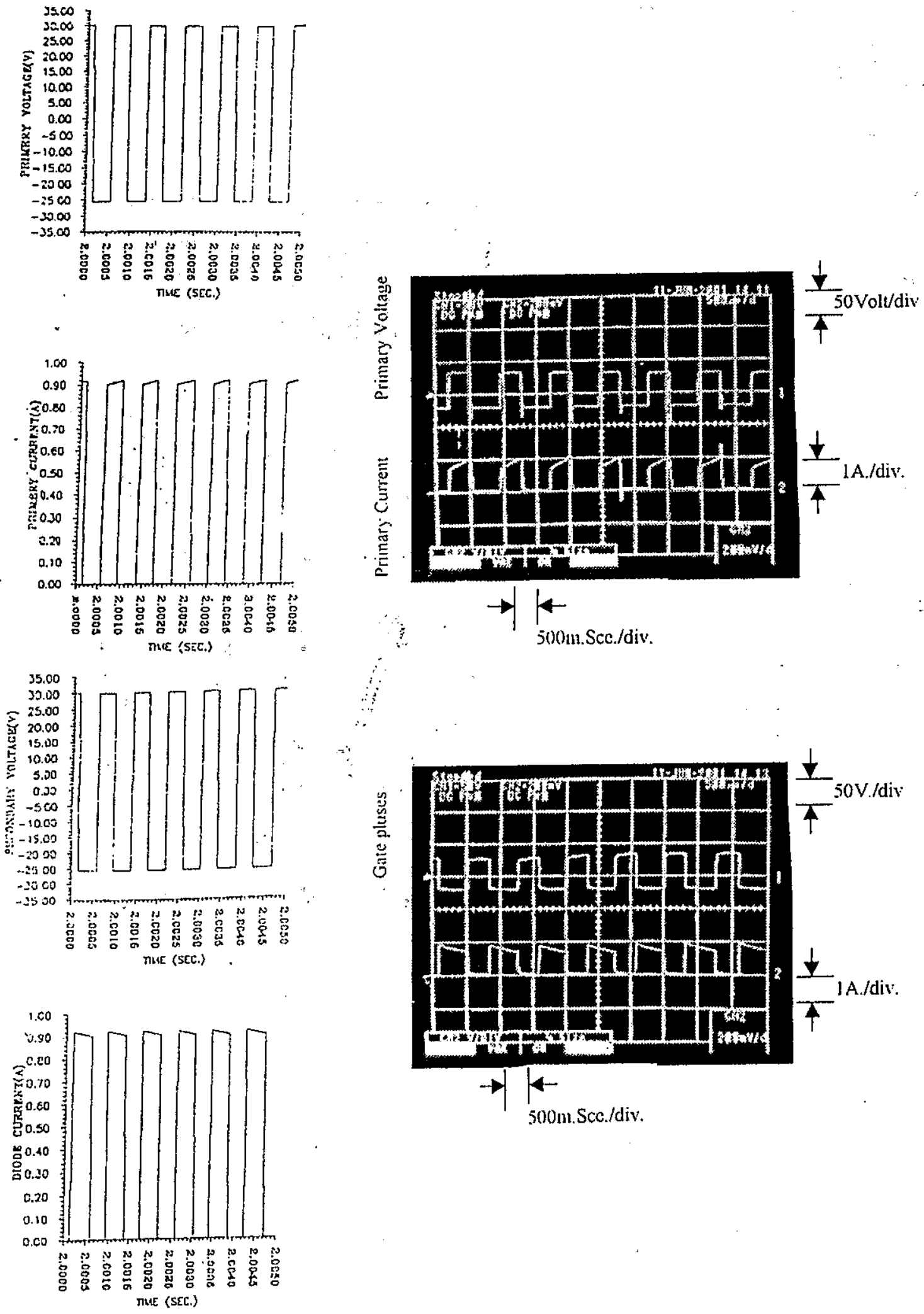

a) Simulation

b) Experimental

Fig.(8): Steady-state waveforms for control voltage $=6$ volt at half full load 
-วnb.101

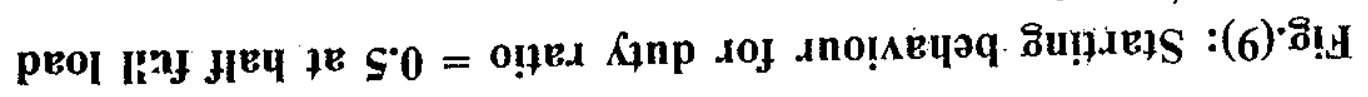

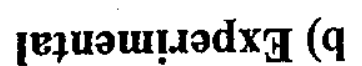

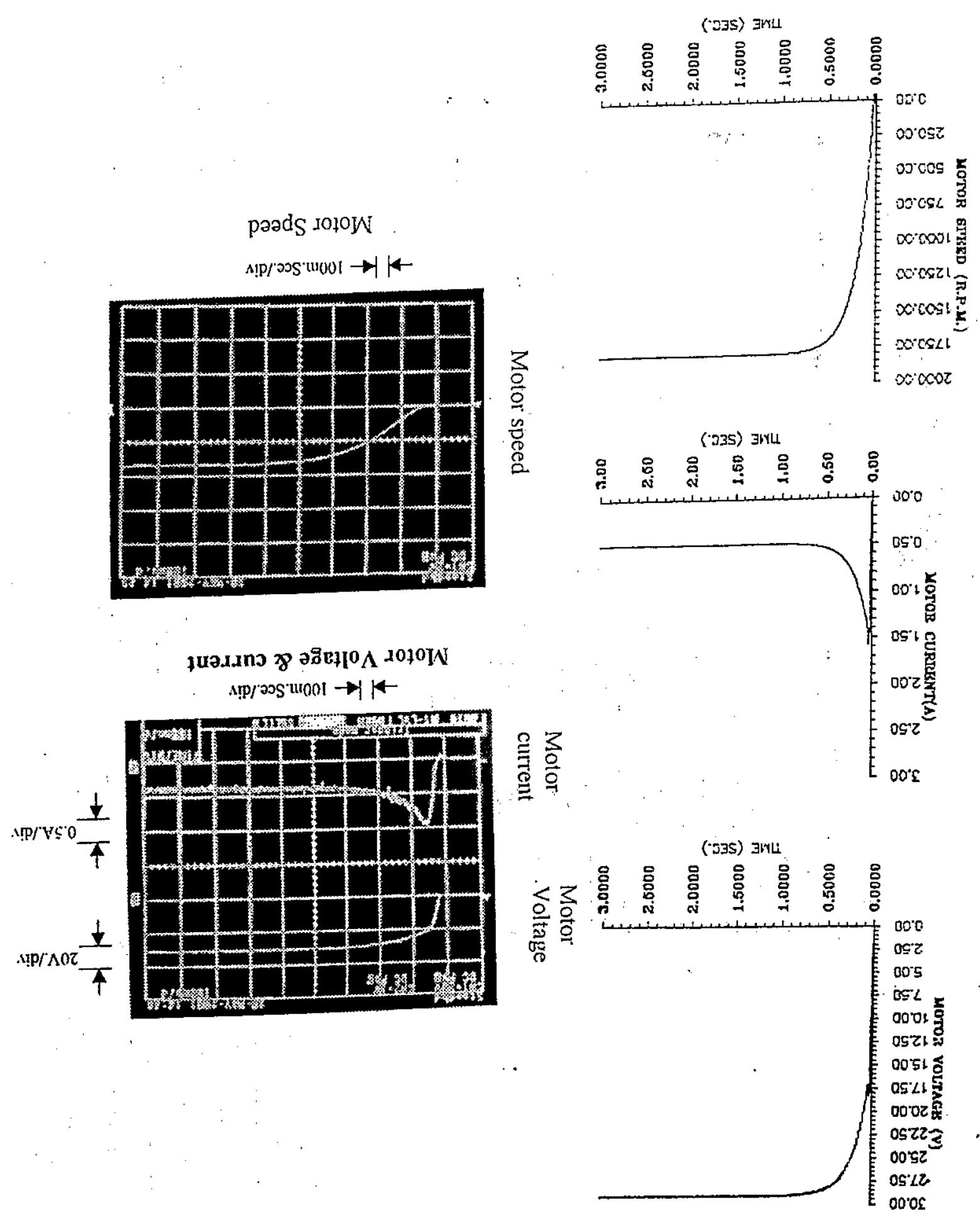




\title{
" خصائص الأداء لمغير الجهد الإرتدادى المغذى "
}

\author{
"محراك ثيار مستمر" \\ د/ مصطفى السيا الشبينى
}

قسم الهناسة الكهربية - كلية الهندسة بشبين الكوم - جامعة المنوفيه

\section{الملخص العريحي:}

يقام هذا البحث إقتراحا للتمثيل العددى لمحرث تيار مستمر ذو تذذية منفصله

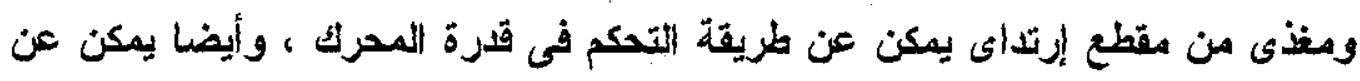

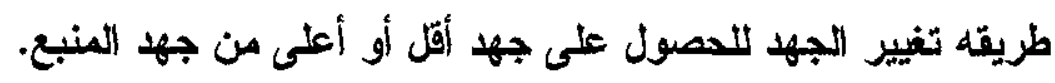

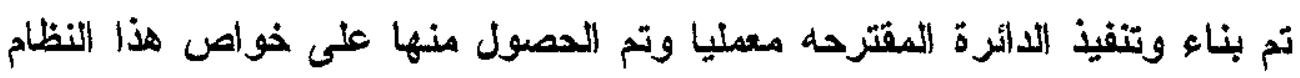

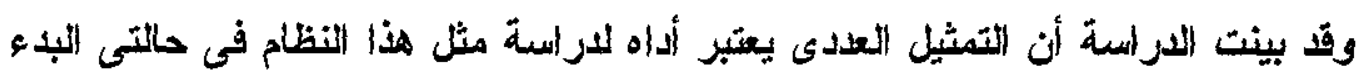
والاستقز الر.

ويشمل هذا البحث دراسة تأثير تيار المجال وأيضا دراسة تغير دليل التعديل على

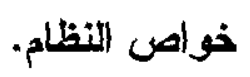
ويتضمن هذا البحث مقارنة بين كل من النتائج المعملية والنظرية ووجد أن هنائك تطابق كبير بينها مما يؤكد صحة الار اسة النظرية لهذا الأداء. 
